\title{
Contribution of buffer zone and community forest programme in household income at Laharepauwa of Rasuwa and Tupche of Nuwakot, Nepal
}

\author{
R Sherchan, K Rijal ${ }^{1 *}$ and SB Bajracharya ${ }^{2}$ \\ ${ }^{1}$ Central Department of Environmental Science, Tribhuvan University, Kathmandu, Nepal \\ ${ }^{2}$ National Trust for Nature Conservation, Khumaltar, Lalitpur, Nepal
}

\begin{abstract}
Historically, Nepal government has been adequately innovative to experiment new conservation and forestry models. The most marked policy shift was the Buffer Zone Management Regulation (1996) which provisioned for buffer zones and $30-50 \%$ revenue sharing with local institutions. Similarly, community forestry, which evolved in mid-70s' has been innovative approach benefiting millions of forest users. The present study attempted to compare buffer zone and community forestry programmes in terms of economic benefits they bring to the local households. Altogether, 274 households were interviewed. Consultation meeting was organized with Langtang National Park office and District Forest Office, Nuwakot. Similarly, key informant interview was carried out with forest guards and key representatives of user's groups. The most prevalent sources of incomes were agriculture and livestock. The result shows $92.4 \%$ households collected forest resources and derived a seasonal income from NTFP in Laharepauwa. The total and mean (HH/year) incomes calculated were respectively US\$ 202,209 and US\$ 1,395 for Laharepauwa and; US\$ 304,316 and US\$2,359 for Tupche. However, a share of buffer zone and community forest programme are only $4 \%$ and $7 \%$ respectively. Buffer Zone program saved 2,351 working days annually or opportunity cost worth US\$11,198. Likewise, Community Forestry programme saved forest collection times worth US $\$ 16,586.4$. The study concludes that direct benefits of these programmes are not significant but indirect benefit by saving resources collection time is substantial. It is imperative to interpret result cautiously as poverty is multidimensional phenomenon and current study didn't consider the capabilities of communities to cope poverty.
\end{abstract}

Key words: Buffer Zone, Community Forest, Household Income, Opportunity Cost

\section{Introduction}

In Nepal, National Parks and Wildlife Conservation (NPWC) Act, 1973 is the first key legal instrument in protecting biodiversity in protected areas. In the same decade, the Nepal govemment issued Himalayan National Park Regulations (1979) which has made special provisions for people living in mountain parks to collect natural resources for their daily requirements, such as firewood, leaf litter, timber and fodder. The Regulation also allows people to graze their domestic animals on park rangeland (Sharma, 1999). However, the marked shift was witnessed in 1996 when Nepal's protected area management system is equipped with Buffer Zone Management Regulation. The regulation incorporated provisions for buffer zones and entrusted Buffer Zone Management Committee to collect the tax from natural resources and utilize as per operational plan. In addition, it also makes provision for 30-50\% of the park revenues for integrated conservation and community

*Corresponding author, email address: sherchanroshan68@gmail.com development programmes in buffer zones. The rationales for delineation of buffer zone are revenue sharing with the local community and to compensate local people affected by wild animals (Paudel et al., 2007).

Outside protected areas, community forestry has been functional for over four decades. Community forestry is a forest management system where usufruct right of the resources is handed over by the government to the local users based on a mutually agreed management plan. The community forestry policy was emerged in mid-1970s when forest national conference in $\mathrm{K}$ athmandu concluded that there was a pressing need to involve local people in forest management (Hobley, 1996). The Forest Act 1993, which is the most significant regulator y development in support of community forestry, guaranteed the rights of local people in 
forest management (MFSC, 1995). With the series of policy changes, it ensured social benefits to local users, marginalized groups and helped empowering women and disadvantaged groups.

Forest products derived through community forestry accounted for $20-25 \%$ of mean household income for 50 households surveyed in one mid-hill district (Chettri, 2004). That ranged from NPR 11, 815 (US \$152) to NPR 20,496 (US \$265) per annum depending on the wealth class. Despite community forestry model is being contested from the equity point of view, there are number of evidences that indicate that local communities are benefitting greatly with having easy access on forest resources, decision making for fixing prices and issuing harvesting permit (Kanel \& Kandel, 2004). The present study aims to compare at what extent, buffer zone and community forest programme are brining in the economic benefits to communities; and to assess local perception in forest resource conservation, use, resource collection time and condition of forest over years.

\section{Materials and methods}

In order to proceed the study, relevant documents were reviewed. Similarly, consultation meeting was performed with the staffs of Langtang National Park Office and District Forest Office, Nuwakot to collect information on potential study areas. Langtang National Park was officially set up in 1971. This is the first mountain national park with an area of $1,710 \mathrm{~km}^{2}$. In 1998, an additional $420 \mathrm{~km}^{2}$ was added to the park as a buffer zone (K arki and McVeigh, 2000). Located in north-central Nepal, the park's souther $n$ boundary extends to north of $\mathrm{K}$ athmandu. It is bounded by the NepalChinese border to the north. Similarly, adjoining district Nuwakot was chosen for inclusion of Community $\mathrm{F}$ orest programme. Framework of k ey parameters (Table 1) was applied during consultation meeting. The potential sites were measured against three categories of parameter, i.e. ecological, social and institutional. The objective of using a framework is to match study areas to the extent possible to reduce observable selection biases.

Table 1 Frame work of parameters for identifying study areas
Syaubari Buffer Zone Community Forest User's Group (SBZCFUG) in Laharepauwa VDC, Rasuwa and Pandey Thumko Community Forest User's Group (PTCFUG), Tupche VDC, Nuwak ot were identified (Fig. 1) through consultation meeting coupled with the aid of framework.

SBZCFUG has been managing buffer zone community forest since 2007. The area of community forest is 141 hectares. Oak (Quercus semecarpifolia), Pine (Pinus roxburghii), Alder (Almus nepalensis) and Rhododendron (Rhododendron arboreum) are the dominant tree species. The total household number was 225 that spread over four villages Kavre tole, Lama tole, Gumbudanda and Bastala (LNPBZSP, 2013). Similarly, PTCFUG was selected in Nuwakot. The total forest area was 117.8 hectares, primarily of Sal ( Shorea robusta) and Alder (Almus nepalensis) species (DFO, 2012). There are 263 households which were located in ward number 3, 4, 5 and 7 . The management responsibilities of forest were handed over to the local community in 1997.

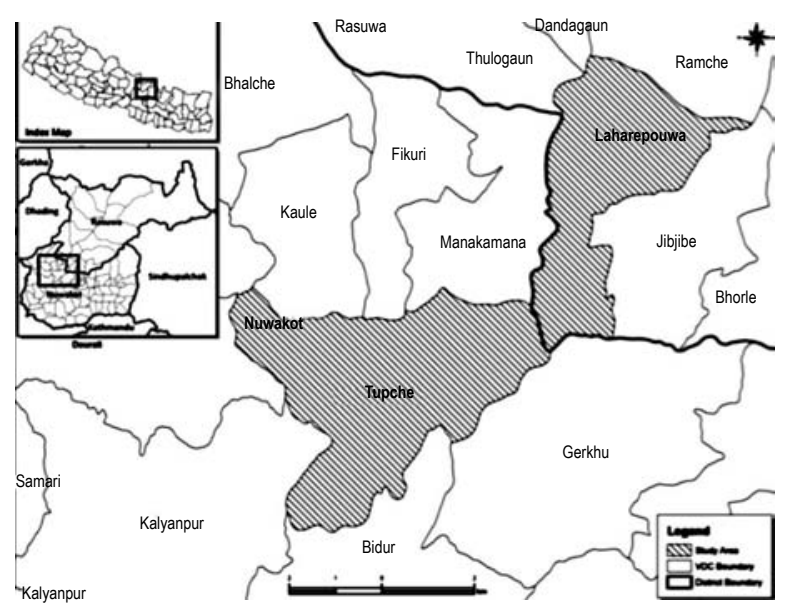

Figure 1 Map of Laharepauwa and Tupche

\begin{tabular}{|c|c|c|c|}
\hline S.N & Ecological parameter & Social Parameter & Institutional Parameter \\
\hline 1. & $\begin{array}{l}\text { Community belongs to Middle mountain } \\
(1200-3000 \mathrm{~m}) \text {, characterized by mixed } \\
\text { broadleaf and conifer forests, high } \\
\text { productivity farming valleys }\end{array}$ & $\begin{array}{l}\text { Pre-dominantly Indigenous } \\
\text { community or mix community } \\
\text { living for long time in that vicinity }\end{array}$ & $\begin{array}{l}\text { BZCFUG and CFUG functional } \\
\text { over five years }\end{array}$ \\
\hline 2. & Size of the community forest $>100$ ha. & $\begin{array}{l}\text { Highly depended on forest resources } \\
\text { for subsistence livelihoods }\end{array}$ & $\begin{array}{l}\text { Currently implementation of forest operational } \\
\text { plan, Institutions ( BZCFUG and CFUG) involved } \\
\text { in conservation activities }\end{array}$ \\
\hline 3. & $\begin{array}{l}\text { The forest ideally includes shrub land } \\
\text { or grazing land }\end{array}$ & $\begin{array}{l}\text { Community with over } 150 \mathrm{HHs}- \\
\text { variance on income level would be ideal }\end{array}$ & $\begin{array}{l}\text { Institutions inclusive in terms of gender, poor } \\
\text { and disadvantaged groups }\end{array}$ \\
\hline 4. & $\begin{array}{l}\text { The BZCF ideally be at the close } \\
\text { proximity or adjoined with park forest }\end{array}$ & Community's reliance also on park areas & $\begin{array}{l}\text { The UG has devised the rules/regulations } \\
\text { pertinent to park office or district forest office }\end{array}$ \\
\hline 5 & Forest functions as wildlife habitats & $\begin{array}{l}\text { Local livelihoods impacted by human } \\
\text { wildlife conflict }\end{array}$ & $\begin{array}{l}\text { UG initiated or aware on HWC issues } \\
\text { or initiated preventive measures }\end{array}$ \\
\hline
\end{tabular}


Two stages sampling strategy was applied i) purposive selection of VDCs and ii) systematic random selection of households. The first household was selected arbitrarily and thereaf ter every $3^{\text {rd }}$ household was approached for inter view. The name list of the user's household was obtained from the user's group. In total, 274 households were interviewed (53\% in Laharepauwa and $47 \%$ in Tupche). The semi-structured questionnaire was used to collect data on household income, reliance on forest resources, forest resources collection time, labor (in-kind) contribution in forest conservation, threats for forest conservation and local perception on representation of women and disadvantages groups on decision making in buffer zone or community forest management. The data was tabulated and analyzed using an excel spreadsheet and STATA. The descriptive summar y (frequency, mean, standard error) and regression were executed as appropriate.

Socio-economic characteristics of sampled households Out of 145 sampled households in Laharepauwa, male and female respondents constitute $53.8 \%$ and $46.2 \%$ respectively. Likewise, in Tupche, $63.6 \%$ were male and $36.4 \%$ female.

Central region of Middle Mountain (1200-3000 msl) is the home of Tamang community along with Brahmin, Chettri and Dalit. Tamang are pre-dominant and traditionally agro-pastoralist, heavily relying on forests and pastureland for subsistence living. The relative importance of animal husbandry to individual households is governed by many factors, including the availability of summer and winter pastures and a reliable fodder supply (Karki \& McVeigh, 2000). Tamang respondents account for $90.3 \%$ in L aharepauwa and $68.2 \%$ in Tupche. Likewise, Newar stands second (8.3\%) followed by Brahmin (1.4\%) in Laharepauwa. In Tupche, Brahmin and Chettri represent respectively second and third highest proportion with $20.2 \%$ and 6.2\%. Dalit represents 3.9\%, while Newar represents only $1.5 \%$. The average family size was found to be slightly higher (5.35) in Laharepauwa compared to Tupche (4.94).

The education status was poor. Majority of community members were not able to attend school due to combined effects of poverty, lack of awareness and education facilities; and absence of incentive. Over $61 \%$ respondents were illiterate. Highest $20 \%$ and $14.8 \%$ had had education only up to the primary level in Laharepauwa and Tupche, respectively. The situation of higher education was very poor as indicated by $0.8 \%$ and $1.5 \%$ respectively. Furthermore, labor intensive farming engaged potential students in subsistence livelihood activities and hindered their education.

\section{Results and discussion Percentage of household involved in income}

Local residents in L angtang National Park are primarily agropastoralist, of which animal husbandry is an essential component and an integral part of the social, economic and religious life of the area (Karki and McVeigh, 2000). This was well supported by the fact that $97.2 \%$ respondents were farmers dependent primarily on maize, millet and paddy. In recent years, farmers have shifted to cash crops (potatoes, vegetables) but number of such households were limited (Bikram Lopchan's personel communication). However, paddy was the major crop in Tupche. The prevalence of household with livestock husbandry was nearly equal (73\%) in study areas. It was not surprising that direct reliance on forest was higher in Laharepauwa as Tamang community are traditionally agro-pastoralist. In addition, 87\% households from Laharepauwa derive income from NTFP, i.e. winter green (Gaultheria fragrantissima) which was not the case for Tupche. Park office, private sector and WWF-Nepal supported in installing an essential oil extraction plant in Syaubari in 2009. Villagers collect leaf and twigs of wintergreen from community forest and make a seasonal income (Mid-August to November).

Households with jobs were 5.5\% in Laharepauwa and 7\% in Tupche respectively. Income from business represents 35.9\% and 14\% in Laharepauwa and Tupche (Fig. 2). The higher proportion of Tamang in business is that they usually brews local wine (Raksi) and makes income. Other activities include small grocery, tea shop and poultry farms. Households with remittance were nearly $26.2 \%$ in Tupche and 37.2 in Laharepauwa. In the study area no substantial income was observed from pension.

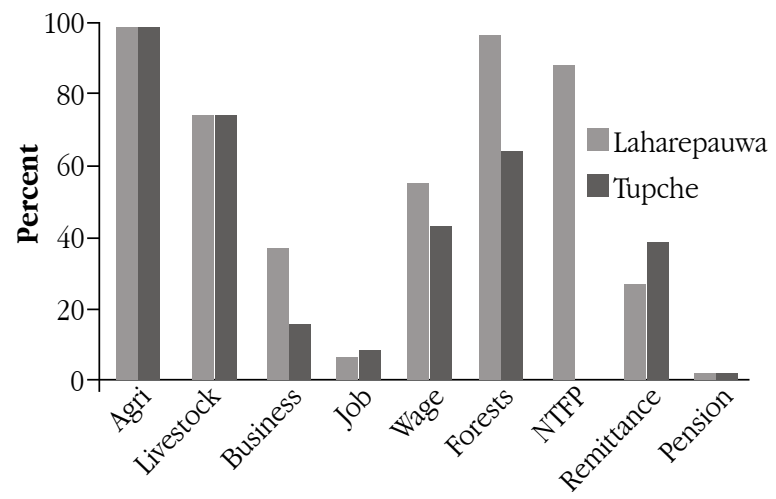

Fig. 2 Household involved in various income sources

\section{Income sources in Laharepauwa, Rasuwa}

A large proportion $(97.9 \%$; $=145)$ of the respondents were found to be involved in far ming followed by forest resources collection (95.8\%). Local people also collect firewood, fodder and leaf litter for household use. The mean annual income of household from forest resources and NTFP were respectively NPR 5,768 (US\$ 55) and NPR . 259.6 (US\$2.5). Similarly , nearly 87\% respondents were found to derive seasonal income from wintergreen which is abundant in buffer zone (Table 2). Park office, private sector and WWF-Nepal have collectively set up oil processing plant. Prior to that, the raw materials were used only for animal bedding. As buffer zone community forest has been managed by SBZCFUG, any benefits from forest resources and NTFPs are attributed to Buffer Zone program. SBZCFUG invests in various 
forest conservation activities, hires forest guard for patrolling, carries out planting of cash crops such as broom grass (Thysanolaena maxima) and Chiraito (Swertia chirayita), holds community meeting for implementing operational plan, conducts silviculture treatments and issues har vesting permit. In return, user households provide labor (in-kind) contribution for forest conservation.

In the study area, household with livestock herding was $73 \%$. Likewise, daily wage constitutes $54.5 \%$ income, though seasonal. The people of mountain adopt multiple sur vival strategies by diversifying their livelihood options. W age labor during slack agriculture season is one such strategy. Kalikasthan, Jhibjihbe and Trisuli Bazzar are the nearest markets where local people work as a wage laborer. It was found to be more rewarding financially as indicated by mean income (HH/year) of NPR 57,125 (US\$ 544).

Agriculture income has been shrinking due to the increased labor costs. This has pushed farmers to shift from on-farm activities to off-farm based wage labors and small business. The annual remittance per household is NPR. 258,486.80. Remittance occupies a highest share and the trend-in-rise is not unique to the study area. This is rather a nationwide phenomenon. According to the report of Department of Immigration of Tribhuvan International Airport, more than 1,500 Nepali youths migrate abroad daily to foreign job market. In Laharepauwa, the total and mean (HH/year) income from remittance were found to be NPR 21.23 million (US\$ 202,209) and NPR 146,427.3 (US\$1,395) respectively.

With respect to the share of income sources of household including the buffer zone programme, the result showed buffer zone programme essentially represents an income from forest conservation and NTFPs. Remittance stands highest (46\%) proportion of share. Agriculture and livestock are collectively contributing $12 \%$ of the income. The share of forests and NTFPs is $4 \%$ which is attributed to buffer zone program (Fig. 3). Others account $16 \%$ income which includes business, job and pension.
It is important to note that poverty is multidimensional phenomenon. Most often, its assessment is based on the current level of welfare, income level, disregarding the capabilities of the communities to sustain or enhance the level (Jodha et al., 2002). This is one such study focused particularly on economic indicator. It is therefore imperative to interpret the result cautiously.

\section{Income sources in Tupche, Nuwakot}

In Tupche, Nuwakot, almost all respondents were farmer. Livestock husbandry engages the second largest proportion of households (72.8\%). Annual mean income from both agriculture and livestock were almost same, i.e. NPR 17,134.7 (US \$ 163.2) and NPR 17,084 (US\$162.7) respectively. Similarly, 62\% HHs were found collecting resources from community forest (Table 3). The mean annual income of forest resources collecting household is NPR 27,461 (US \$261.5). This income was 4.75 folds higher than Iaharepauwa, Rasuwa. The possible explanations were har vesting seasons; procedures of resources collection and their distribution, which is well regulated by SBZCFUG in Laharepauwa. On the other hand, no such regulation was observed in Tupche. The forest resource use practices are extractive. Sustainable forest development and conservation were an issue. No social benefit was derived from NTFPs. The total and mean annual income are respectively NPR 31.953 million (US\$304,316) and NPR 247,699 (US\$2,359).

Remittance contributes 58\% household income (Fig. 4). There is a widespread trend of youths out-migration to gulf countries and India. In forest resources category, income share from fuel wood, fodder and leaf litter was 7\%. The result shows no income was derived from NTFPs. Agriculture with livestock constitute 12\%, whereas wage represents $11 \%$ income (Fig. 4). The share of wage labor in Tupche is half, compared to Laharepauwa. The possible explanations for low share of wage labor was that far mers have large landholding and harvest good quantity of paddy. But, market is far and not connected with road network, thus consumes longer time of the farmers.

Table 2 Income and its share in Laharepauwa

\begin{tabular}{lcrrrc}
\hline Sources of Income & Frequency & Mean Income & \multicolumn{1}{c}{ Std. Err } & Income (NPR.) & Share (\%) \\
\hline Agriculture & 141 & 5290.81 & 575.72 & $746,004.21$ & 3.51 \\
Livestock herding & 106 & $16,405.93$ & $2,026.58$ & $1,739,028.58$ & 8.19 \\
Busi ness & 52 & $47,922.12$ & $11,118.85$ & $2,491,950.24$ & 11.74 \\
Job & 8 & $57,125.00$ & $21,089.47$ & $457,000.00$ & 2.15 \\
Daily wag e & 79 & $60,518.99$ & $7,325.86$ & $4,781,000.21$ & 22.52 \\
Forest resouces & 139 & $5,768.09$ & 200.88 & $801,765.07$ & 3.78 \\
NTFP/Winter green1 & 2 & 6259.63 & 34.11 & $32,714.00$ & 0.15 \\
Remittance & 38 & $258,486.80$ & $42,672.74$ & $9,822,498.40$ & 46.26 \\
Pension & 2 & $180,000.00$ & $60,000.00$ & $360,000.00$ & 1.70 \\
Total Income & & & & $\mathbf{2 1 , 2 3 1 , 9 6 0 . 7 0}$ & $\mathbf{1 0 0 . 0 0}$ \\
Mean Income & & & & $146,427.32$ & \\
\hline
\end{tabular}

US\$1 =NPR 105

\section{喻 TU-CDES}


Table 3 Income and its share in Tupche

\begin{tabular}{lcrrrc}
\hline Sources of Income & Frequency & Mean Income & \multicolumn{1}{c}{ Std. Err } & Income (NPR.) & Share (\%) \\
\hline Agriculture & 128 & $17,134.78$ & $1,180.99$ & $2,193,251.84$ & 6.86 \\
Livestock & 94 & $17,084.57$ & $1,668.61$ & $1,605,949.58$ & 5.03 \\
Business & 18 & $30,161.11$ & $4,423.77$ & $542,899.98$ & 1.70 \\
Job & 9 & $306,666.70$ & $80,606.73$ & $2,760,000.30$ & 8.64 \\
Forest resources & 80 & $27,460.94$ & $5,257.03$ & $2,196,875.20$ & 6.8 \\
Daily wage & 53 & $66,211.32$ & $9,992.28$ & $3,509,199.96$ & 10.98 \\
Remittance & 48 & $388,854.20$ & $29,535.63$ & $18,665,001.60$ & 58.41 \\
Pension & 2 & $240,000.00$ & $120,000.00$ & $480,000.00$ & 1.50 \\
Total income & & & & $\mathbf{3 1 , 9 5 3 , 1 7 8 . 4 6}$ & $\mathbf{1 0 0 . 0 0}$ \\
Mean income & & & & $247,699.06$ & \\
\hline
\end{tabular}

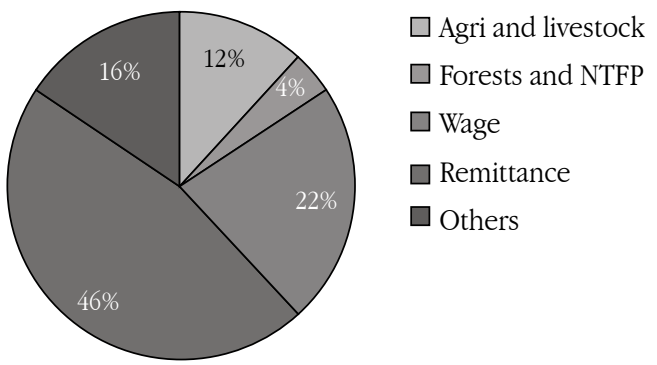

Fig. 3 Share in household income in Laharepauwa

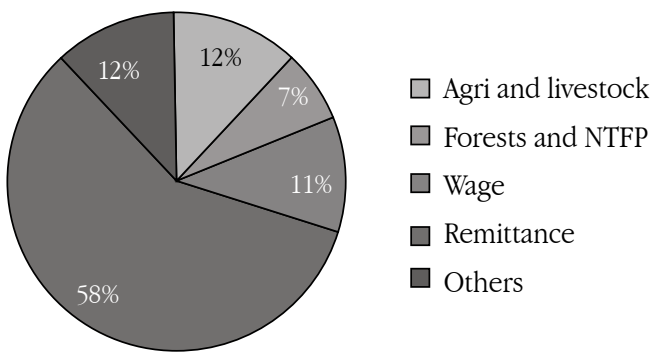

Fig. 4 Share in Household Income, Tupche

\section{Quantity of forest resources, collection time and opportunity cost}

Household survey revealed that the forest resources collection time has been reduced after local institutions have managed buffer zone forest or community forests. The SBZCFUG managed buffer zone community forest in Laharepauwa since 2007. On the other hand, PTCFUG has been managing community forest in Tupche since 1997 . The community based management has resulted in to increased forest coverage and easy accessibility of forest resources, i.e. fuel wood, fodder and leaf litter. Though local users have an access to timber, the study found that local people use timber only for household use. The quantity of timber extraction per household was also less, thus not accounted in income calculation. However, as quantity of collection of fuelwood, fodder and leaf litter were substantial and extraction was of repetitive nature, estimation was done for these resources in ter ms of collection time and opportunity cost. Mean hours, total hours and number of working days saved were estimated. While estimating working day, 8 hours is considered equal to one working day. The study calculated monetary value by multiply saved collection time with NPR 500, which was the prevailing daily wage for unskilled labor.

Mean annual quantity (HH/year) of fuel wood, fodder and leaf litter collected in Laharepauwa were respectively 6.74, 7.84 and 6.39 bundles. The bundle (bhari) is the local unit that varies in weight from types of forest resources. Generally, a bundle of fuel wood weighs $25-30 \mathrm{~kg}$ whereas bundle of fodder and leaf litter weigh roughly $12-18 \mathrm{~kg}$. Earlier, when forest was not managed by local users, the mean collection time for a bundle of respective forest resources were $9.8 \mathrm{hr}$., $9.66 \mathrm{hr}$. and $9.58 \mathrm{hr}$. The cur rent mean collection time has reduced to 2.1, 1.95 and 2 hours (F ig. 5). The reduction in collection time has saved annually 51.9, 60.5 and 18.2 hours for forest dependent households. In total, buffer zone community forest programme saved 2,351 working days which is equivalent to NPR. 1.175 million (US\$11,198) per annum. In addition, SBZCFUG supported replacing wooden pole by iron for 53 households. With religious purpose, each individual Tamang household erects pole exerting recurrent pressure to forest. Now with the support of iron pole, this has saved hundreds of poles in the community forest.

Reduced resources collection time entails reduced opportunity cost which other wise, could be spent on appropriate income generation activities. This is the social welfare brought by buffer zone or community forestry programme. However, it is important to note that saved time has to be converted in to cash income for being truly benefited.

In Tupche, mean quantity of fuelwood, fodder and leaf litter collected per household were 34.84, 50.74 and 19.35 bundles respectively. Likewise, 3483 working days in a year are saved, which is equivalent to NPR. 1.74 million (US\$16,586.4). This value is 48.1\% higher than Laharepauwa. 


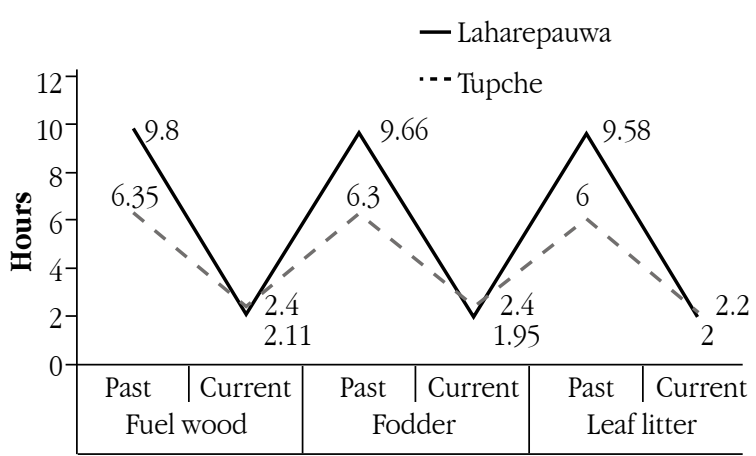

Fig. 5 Resources collection time (hours) of fodder, fuel wood and leaf litter in Laharepauwa and Tupche

\section{Local perception on conditions of community forests}

The study assessed the perception of local community on the condition of forest changed over years. In L aharepauwa, nearly $71 \%$ respondents opined that community forest is "highly improved" followed by 28.3\% "improved", 1.4\% respondents expressed "don't know" (Fig. 6). No respondent expressed that forest is degraded which confir ms that SBZCFUG have been managing forest well. The positive perception was much in the line of outcomes of strong forest management and strict regulation related to forest resources during har vesting by users. On the other hand, in Tupche, nearly 11\% respondents expressed that forest condition is "degraded", $41.8 \%$ responded that community forest is "improved" and 29.5\% expressed forest condition as "highly improved". The higher rate of extraction of forest resources might have led to forest degradation. During the study , $12.4 \%$ respondents were not sure about the condition, whereas nearly $6 \%$ respondents replied forest condition "not changed" (Fig. 6).

\section{Association of landholding with agricultural income}

In Laharepauwa, the regression analysis indicates that there is no significant relationship between landholding and agricultural income ( $\mathrm{df}=140, \mathrm{R}^{2}=0.06 \%, p>0.05$ ) (Table 4). The low $\mathrm{R}^{2}$ value $(0.06 \%)$ suggests that change in landholding didn't explain the variability in agricultural income well. This result seems to be surprising, but this is likely to be caused by the increased labor

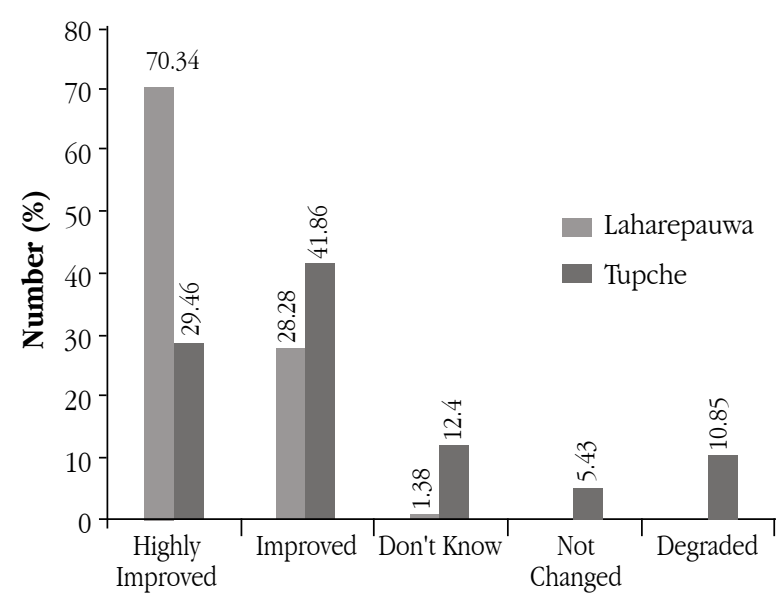

Fig. 6 Local perception on condition of forest (\%)

cost, crops raid from wild animals and fluctuating market prices. On the other hand, there is a significant relationship with livestock income as indicated by $p$-value (0.014) less than $0.05(\mathrm{df}=105$, $\mathrm{R}^{2}=5.56 \%$, coeff. $\left.=0.0000328\right)$. However, the positive association with livestock income in Laharepauwa might be explained by the fact restriction of grazing inside park pastureland favors households with large landholding with adequate supply of fodder and leaf litters from private sources. In T upche, association between landholding with agriculture income is significant $\left(\mathrm{df}=127, \mathrm{R}^{2}\right.$ value $=3.2 \%, p<0.05)$. On the other hand, no significant relation was found with livestock income $(p$ value $=0.776$ ).

\section{Conclusion}

Syaubari Community Forest user's group was found to be active in forest patrolling, NTFPs cultivation and regulating har vesting season and procedures. This has resulted in to forest cover increment which is substantiated by "highly improved" response by nearly $71 \%$ respondents. On contrary, the community forest in Tupche experienced nearly five folds resources extraction. It appears that sustainable forest management is an issue in Tupche, Nuwakot. Regarding contribution of buffer zone and community forestry programmes, their share was low respectively $7 \%$ and $4 \%$. However, programmes have benefited users greatly by reducing the resources collection time. In Laharepauwa, community-based forest management has saved 2351 working days or opportunity

Table 4 Association of landholding with income from agriculture and livestock

\begin{tabular}{lcccc}
\hline Statistics & \multicolumn{2}{c}{ Agricultureal income } & \multicolumn{2}{c}{ Income from Livestock } \\
\cline { 2 - 5 } & Laharepauwa & Tupche & Laharepauwa & Tupche \\
\hline Number of observation & 141 & 128 & 106 & 94 \\
$\mathrm{R}^{2}$ & 0.0006 & 0.0316 & 0.0565 & 0.0009 \\
Prob $>$ F & 0.77 & 0.0447 & 0.0142 & 0.7755 \\
Df & 140 & 127 & 105 & 93 \\
Coefficient & $9.31 \mathrm{E}-06$ & 0.0000799 & 0.0000328 & 0.0000119 \\
Standared Err. & 0.0000318 & 0.0000394 & 0.0000132 & 0.0000416 \\
p value (95\% CI) & 0.77 & 0.045 & 0.014 & 0.776 \\
\hline
\end{tabular}


cost worth NPR. 1.175 million (US\$11,198) per annum. In Tupche, the figure was 3,483 working days, equivalent to NPR. 1.74 million (US\$16,586.4). The study concludes that though there were no significant direct benefits, reduction in resources collection time is a social welfare gain, if those time can be utilized in income generation activities.

\section{Acknowledgements}

The authors duly acknowledge support extended by Syaubari Buffer Zone Community Forest User's Group, Rasuwa and Pandey Thumko Community Forest User's Group, Nuwakot. The authors are also thankful to Mr. Bikram Lopchan, Secretary of Syaubari User's Group, Mr. Mohan Aryal and Mr. Sandeep Poudel for support in data collection, Mr. Bed Kumar Dhakal, then Chief Conservation Officer, Langtang National Park; Mr. Gautam Poudel, Project Manager, Langtang National Park and Buffer Zone Support Programme and Ranger of District Forest Office, Nuwakot for providing valuable infor mation about the study areas and Department of National Parks and Wildlife Conservation (DNPWC) for granting research permission.

\section{References}

Chettri, A. (2004). Extraction of NTFPs from the community forest: Analysis of benefit distribution pattern in household level. Journal of Forest and Livelihood, 4, 38-43.

DFO, Nuwakot. (2012). The Analytical Progress Report. District Forest Office, Nuwakot.
Hobley, M. (1996). Participatory Forestry: The Process of Change in India and Nepal, Rural Development Forestry Study Guide 3, ODI, London.

Jodha, N.S., Bhadra, B., Khanal, R.K., Richter, J (2002). Poverty Alleviation in Mountain Areas of China. In Jodha S., Narpat, Bhadra, B., Khanal, R.K., Richter, Jand, J. (Eds.) Proceedings of the International Conference (pp. 10), 11-15 November, 2002, Chengdu, China.

Karki, J., McVeigh, C. (2000). Status Paper of Langtang National Park. Grassland Ecology and Management in Protected Areas of Nepal. Technical and Status Papers on Grasslands for Mountain Protected Areas 3, pp.121-132.

Kanel, K.R., Kandel, B.R.(2004). Community forestry in Nepal: Achievements and challenges. Journal of Forest and Livelibood 4, 55-63.

LNPBZSP, Rasuwa. (2013). The Annual Progress Report, Langtang National Park and Buffer Zone Support Project, Rasuwa.

MSFC (Ministry of Forest and Soil Conservation) (1995). Forest Act 1993 and Forest rules and regulations 1995. Kathmandu, Nepal: Government of Nepal.

Paudel,N.B., Budathoki, P., Sharma, U. (2007). Buffer Zones: New Frontiers for Participatory Conservation? Journal of Forest and Livelibood, 6, 44-53.

Sharma, U.R. (1999). Country Paper Nepal. In K.P. Oli, (Ed.) Collaborative Management of Protected Areas in the Asian Region (pp 49-59). IUCN-Nepal, Kathmandu. 